\title{
CONFIDENCE AND MOTIVATION OF NOVICE ENGLISH TEACHERS AT VNU IN CONDUCTING RESEARCH
}

\author{
Le Thuy Lan* \\ Faculty of English Language Teacher Education, \\ VNU University of Languages and International Studies, \\ Pham Van Dong, Cau Giay, Hanoi, Vietnam \\ Received 26 July 2019 \\ Revised 19 December 2019; Accepted 15 February 2019
}

\begin{abstract}
The study aims to gain some insights into the confidence and motivation of young English teachers in doing research as a preliminary stage for further follow up research into the research practice of these teachers. The researcher opted for a qualitative approach by interviewing in person six novice English teachers working at a university in Vietnam National University, Hanoi. The outcomes show that the teachers had between low and medium confidence in their research ability and were motivated mainly by extrinsic factors such as school requirement while acknowledging the benefits research has on teaching practice and personal development.
\end{abstract}

Keywords: teacher's professional development, teacher's research, teacher's confidence, teacher's motivation

\section{Introduction}

\subsection{Research as part of teacher's competences}

It is of a longheld belief that one significant competence that good teachers must possess is the ability to conduct research in order to inform their teaching practice. Studies have reached the general concensus that teachers who read and do research on a regular basis make research-based pedagogical decisions which in turn positively benefit both teaching and learning (Rowland, 1996; Hargreaves, 2001; McNiff \& Whitehead, 2012). Moreover, research doing has also been proven to favour teachers' own professional development (Kincheloe, 2003; Lyle, 2003; Lankshear \& Knobel, 2004; Kirkwood \& Christie, 2006; Chow, Chu, Tarvares, \& Lee, 2015).

Also, for higher education, research has been cited as one fundamental responsibility

* Tel.: 84-346704739

Email: lanalee9588@gmail.com of university teachers alongside teaching (Rowland, 2006). In the book Reflective Teaching in Second Language Classrooms, Richards and Lockhart (1994) also stated six major roles of language teachers including material developer, counselor, mentor, team member, professional and researcher. Specifically, teachers are recommended to conduct research related to the language learning and teaching, especially in their classroom context.

\subsection{Research requirements of teachers at $V N U$}

In the light that Vietnam's higher education system is striving towards enhancing its quality and position in the world stage of education service, Vietnam National University, (abbreviated as VNU) - as the number one university in the country (ranked by QS Asia 2016) is playing a pivotal role in such process. The university has publicly announced its ambitious goal to become the leading research institution in the region, to make it to the top 100 universities in Asia and 
top 500 universities in the world by the year 2020 (VNU, 2014). In order to realise this goal, the university acknowledges the utmost importance of research as a central criterion to work on, and accordingly has impelled its own teaching staff to step up and get more actively involved in research-related activities. To be specific, with an aim to help VNU reach 800 articles published on international journals by 2020, the University of Languages and International Studies (ULIS) - a member university of VNU has required that any inservice teacher at VNU must work least 600 hours of research per year, which is equivalent to at least one research article published on internationally recognised journals or the like (University of Languages and International Studies, 2017). This is an awarding effort in order to liven up the research environment in the university, yet has inevitably caused certain challenges to its teachers, especially novice teachers with relatively little experience not only in instructional teaching activities but also research-oriented ones.

\subsection{Novice teachers}

The study into the first years of novice teachers has been a well-established literature. Novice teachers - teachers with less than five years of experience in the job - are found to encounter enormous challenges in theinduction period of their career. These include classroom management struggles, unsupported working environments, inadequate preparation time, lack of administrative support (Dickson, Ridlebarger, Stringer, Tennant, \& Kennetz, 2014). However, research literature leaves a gap of novice university teachers who are required to conduct research along with their teaching job but find themselves fall short in both experience and orientation in such a complicated and highly demanding academic practice.

In summary, research has become a basic requirement for teachers at $\mathrm{VNU}$; however, it might pose a problem for young teachers with little experience both in teaching and researching. More specifically, in her own teaching faculty, the researcher has also noticed that many of her colleagues who are young teachers seem to have rather low confidence and little motivation when it comes to doing research. Therefore, the researcher wishes to gain a clearer insight into the exact confidence level and motivations of novice teachers in research practice by conducting this study.

\section{Literature review}

\subsection{Novice teacher's confidence in doing research}

Several definitions of confidence have been put forward. Bandura (1977) comes up with a term called self-efficacy and defines it as one's belief in their capabilities to attain certain set outcomes. Building on this definition, Craig (2007) slightly differs and thinks of confidence as a combination of selfefficacy and positive belief about future as well trust in other people. In this study, based on Bandura's (1977, p.3) original definition of self-efficacy, the researcher refers to teacher's self-confidence in doing research as teachers' own beliefs in their abilities to "organize and execute the courses of actions required to produce given attainments" in conducting research.

It is a matter of fact that even though many studies have been made into teacher's self-efficacy or confidence in their teaching practice, little has been investigated about teacher's confidence in doing research as part of their professional development, not to mention novice teachers'. Previous studies such as Hancock's (1997) study found that participating teachers did not show a high level of confidence in assuming roles of researchers but rather seemed disoriented due to the incessant reforms, revisions and adjustments initiated by the British government. The teachers also claimed to believe they themselves "have little part in making changes" and "believe less in 
themselves as professionals with something worthwhile to say" (p.90). One particular survey by Gray and Campbell (2002) distributed to 200 new university graduates in teaching profession shows these beginning teachers had a prevailing survival mindset but simultaneously demonstrated an open mindset to coming opportunities in their future career and confidence in joining the school community of inquiry.

\subsection{Novice teachers' motivations in doing research}

Another significant factor that might influence young teachers' research activities has to do with their motivation, which is in close connection with their confidence level. Bandura himself conducted more studies into the matter of self-efficacy or confidence and found a strong correlation between one's confidence in their own abilities to achieve desirable outcomes and their motivation in carrying out tasks. Motivation is considered the energy and drive that moves people to do something. According to Deci and Ryan's (1985) Organismic Integration Theory, there are three types of motivation, the first of which is intrinsic motivation including interest, enjoyment and inherent satisfaction or, in other words, people are driven to do something because the activity itself is interesting or enjoyable. The second type of motivation is extrinsic motivation which can be further divided into four kinds (Ryan \& Deci, 2000b) known as:

(1) external regulation or behaviors to satisfy external demand or rewards (compliance, external rewards and punishment);

(2) introjected regulation or behaviors to avoid guilt or anxiety or to attain ego enhancement (self-control, egoinvolvement, internal rewards and punishment);

(3) identified regulation or a conscious valuing of a behavioral goal or regulation (personal importance, conscious valuing);
(4) integrated regulation which occurs when identified regulations are fully assimilated to the self (congruence, awareness, synthesis with self).

The final type of motivation is actually the lack of motivation or amotivation.

Based on Deci and Ryan's definition of motivation, teacher's motivation in doing research can be understood herein as a factor driving teachers to do research. Watkins' (2006) early study shows that teachers were mainly motivated to conduct research for their own professional development as it allowed them to view the teaching practice from an outsider' standpoint, learn about other teachers' techniques and relate research findings with their own classroom instruction as well as establish social networking. Borg's (2009) mix-method study on research practice among 505 English language teachers across different countries found that teachers were mainly motivated to do research by practical and professional concerns rather than external factors such as employers or promotion. Some years later, in 2015, Mehrani at the University of Neyshabur conducted interviews with 24 Iranian English teachers and found a modest level of research engagement. The Iranian teacher participating in the study reported a variety of motivations, including their professional development, pedagogical concerns, instrumental incentives, and institutional expectations, among which the first two personal motivations also played the major role. However, Ulla's (2018) qualitative research among 11 public high school English teachers in Mindanao Philippines found that participating teachers were motivated by personal rather than professional goals to do research. At the same time, they also acknowledged the benefits for their teaching practices and career development that research could bring.

In Vietnam, Phan (2011) conducted research into research activities at Hue University and found that over $65 \%$ of lecturers chose passion, realizing research ideas and supporting teaching practice as their motivations for doing research. Almost 
$60 \%$ of teachers claimed that they do research because of compulsory requirements. Whereas, extrinsic motivations such as to improve chance of promotion or annual performance evaluation accounted for a much smaller proportion at $30.3 \%$.

In general, it is apparent that there exist certain discrepancies among aforementioned research outcome on the motivations of teachers in conducting research. Most of the found research was conducted in other countries, only which by Phan (2011) shed some light into Vietnamese teachers' motivations in doing research. However, Phan's research is a quantitative one, which in turn limits the insight it may provide about the matter in question. The researcher herself, hence, looked forward to conducting her own qualitative study into the motivations of novice teachers in her teaching institution to contribute to the available literature.

\section{Research design and methodology}

\subsection{Scope of study}

The researcher has decided to look into confidence and motivation in doing research of six English teachers at Vietnam National University - Hanoi in Vietnam.

\subsection{Research questions}

1. How confident are novice English teachers at VNU in doing research?
2. What are the novice teachers' motivations in doing research?

\subsection{Research methods}

\subsubsection{Sampling}

The study employs criterion sampling method in which a number of pre-set criteria were used in selecting participants. To be more specific, participants in the study must meet the following requirements:

i. Participant must be an in-service teacher at VNU in Hanoi.

ii. Participant must have less than five years' experience as an in-service teacher.

iii. Participant must have had conducted at least one research.

iv. Participant must agree to willingly take part in the research on the grounds that their identity remains strictly anonymous and the information they provide is used only for research purpose.

After approaching all the teachers that satisfy the requirements above, the researcher received approval to interview six young teachers with under five years of teaching experience at VNU. They are predominantly holders of bachelor degrees currently pursuing master program and some are master graduates. The following table shows a description of their profile, noted that they are introduced under pseudonyms to preserve their identity and the confidentiality of collected data.

Table 1. General information about participants

\begin{tabular}{|c|c|c|c|}
\hline Pseudonym & Gender & Teaching experience & Research experience \\
\hline Phuong & Female & 1.5 years & 2 studies \\
\hline An & Female & 1.5 years & 2 studies \\
\hline Binh & Female & 3 years & 2 studies \\
\hline Ha & Female & 3 years & 3 studies \\
\hline Thanh & Female & 4 years & 3 studies \\
\hline Hoang & Male & 3 years & 5 studies \\
\hline
\end{tabular}

All in all, by gender, there are five female participants as opposed to one single male participant. Most of them have between 1.5 to 4 years of work experience, with half of them having been a lecturer for 3 years. In terms of research experience, the participants all claimed to have certain experience, with at least two studies done for each person and 
at most 5 for the male lecturer. Their studies are mainly in the field of English Language Teaching and Linguistics as these are also two strong majors of the faculty. Some studies they have conducted are their graduation papers from bachelor degree or master degree course, whereas some were conducted during their working time at their faculty as a lecturer.

\subsubsection{Data collection instrument}

The researcher collected data using the qualitative method of individual face-to-face interview over the course of two months, in February and March 2019. The language medium of the interviews was English because all the participants were English language teachers with high proficiency in the language and they themselves claimed to have no problem with using the language for interviews. Each interview lasted for an average of 20 to 40 minutes. All the interviews were recorded with consent of participants for the purpose of data analysis later on. The interview was conducted in a semi-structured manner, in which a set of guiding questions and prompts were prepared in advance by the researcher, yet the questions remained open-ended and the interviewees were expected to elaborate on their points by giving details and reasons.

The interview included two major sections. The first one asked about participants' background and experience in teaching as well as researching. The next part contained questions about their self-confidence and motivation in doing research.

\subsubsection{Data analysis}

The researcher decided to opt for content data analysis upon perceiving its appropriateness. In details, after interviews took place, recordings were transcribed into written texts through the computer by the researcher herself and filed into a common database using Microsoft Excel. Importantly, it is noted that the questions in the questionnaire were organized into two themes 'confidence' and 'motivations', so the answers gained from those questions were analyzed accordingly. Specifically, the research looked for common themes among the answers of six participants for one question at a time while highlighting differences in those answers to report in the results.

\section{Results}

\subsection{Research question 1: Novice English teacher's self-confidence in doing research}

To begin with, so as to best visualize the level of confidence, the participants were first asked to rate their self-confidence in doing research on a scale of 1 to 5 , with 1 being "not confident at all" and 5 being "highly confident" before they explained their choice. Most of the young lecturers in the study scored themselves between $\mathbf{2}$ to $\mathbf{3 . 5}$ on this question, showing that they were not quite confident in this practice. More specifically, three teachers (An, Binh, and Phuong) each chose 2 to 2.5, explaining that they do not think of themselves as good researchers.

An said "I'll give myself 2. I don't think I have enough insights into my specialized field. I don't know what to research, what should be researched, what is the research gap we need to fill in. Most of the time, it is intuitive..."

Meanwhile, Binh appeared to be even more negative about her research ability, "I think would be 2. Although I've made considerable efforts, I didn't find myself good at doing research. It's not my strong point, not my interest as well. I think the most important reason for that is my lack of interest in doing research. I'm not willing to overcome difficulties to pursue it anyway; I find it really a huge weakness and a nightmare for me."

On the other hand, the remaining teachers including Thanh, $\mathrm{Ha}$ and Hoang answered with a bit more confidence by giving themselves between 3 and 3.5 on this question. In response to the question why not a higher score, Hoang admitted that he has "just a little experience, doesn't have too much passion in doing research, still has a lot of questions". Only $\mathrm{Ha}$ managed to give herself a 3.5, 
claiming that she likes doing research, yet was "not really confident, because I don't have much knowledge about research methods even though I've learnt a lot about methodology. When it comes to really practice researching, I have a lot of difficulties, what I need to do, what to do next, a lot of questions."

In order to solidify the answers gained from the previous question, the researcher decided to ask a further question on how strong the participants think their research skills are, which also partly reflects their confidence level in this practice. Accordingly, the participants were requested to rate their research skills from 1 - extremely weak to 5 - extremely strong. Interestingly, a similar outcome to the first question was recorded as all of the participants chose between 2-3 points for themselves in this question, showing a rather low confidence in their research skill.

Phuong said "It's kind of embarrassed. I think my skill is not fully developed enough for me to carry out the research on my own, I usually need the support from a lot of resources and other people that I met to figure out the way, or ask them for help or some kind of support."

Binh went as further to show her many worries about her own research skill: "After reading a bunch of material, after being exposed to a lot of data, I'd be really confused, overwhelmed by the huge amount of information. I would find it really difficult to analyze them, to synthesize in a logical and like... effective way to generate useful finding. How to say, even though I tried to come up with some amazing findings, my mentor said that it's not really amazing, not useful. I'm not really good at that."

The final question in this part asks about how well-trained in research methodology they think they are. The researcher intends to find out the reason for such low level of confidence shown by participants, which might to some extent correlate to their previous training experience in research activities at school or during the induction period. Surprisingly, this time, a wider range from 1 to 4 was reported, with most participants opting for either 3 or 4 . This could be put down to the fact that most of them admitted having received formal training in research methodologies through courses at university or higher education classes even though they admitted not having made good use of such knowledge until now. The only exception was Phuong who gave herself only 1 , confessing to have no proper training of any kind during her time as a student, and all the research she had done so far had been based on her own experience and informal guiding from others.

To further understand the teachers' confidence in doing research, a special question was asked about how they feel when conducting studies. It is assumed that high level of confidence in doing research might be followed by positive feelings toward this practice whereas low level of confidence may lead to somewhat more negative feelings. As a result, a range of both positive and negative adjectives to describe participants' feelings toward their research doing were recorded. Specifically, on the negative side, most teachers would say they feel "nervous, pressured, stressed, confused, tired, exhausted, lost" when doing research.

I do feel pressured that I know I must complete the scores. I must do it immediately and have enough score. Also confused as I don't know the orientation, how to do it. This feeling occurs at the beginning of each phase. And finally tired when I have done it (the research) for too long. - Hoang.

It's a bit stressful, exhausted. I don't think it's useful. There are many stages in doing research, right? It takes about 1 or 2 months to complete one, I have to say that's a lot of time, I kind of prefer spending my time doing other things instead of research. - Thanh

I think the more I dig deeper, the more I'd be lost. Because there's a lot of information, even contrasting information, even information that would make me have $2^{\text {nd }}$ thought about my opinion at the first stage. Sometimes I cannot use my data because it didn't answer my research question at all, or some of the findings 
are really opposite to my hypothesis. - Binh

On the other hand, a smaller number of positive feelings were reported as follows:

I'm really curious about the results. Before I do the research, I have some kind of assumptions in mind, I'm really curious about what is really in reality. I also feel engaged as I really want to find out what is in the end finally. That's why I get really engaged in the research." - Ha

I feel deeply joyful when I read some meaningful papers around the world. - An

All in all, it is safe to conclude from the interview findings that most of the teachers in the study showed a low to medium level of confidence in their research skills despite having been trained quite properly in research methodologies. This is further supported by the fact that most of the teachers have certain negative feelings such as being pressured, nervous, lost while doing research even though some of them do have positive attitude towards this practice.

\subsection{Research question 2: Novice English teachers' motivation in doing research}

As for the current study, when asked about their motivations in doing research there is a consensus among participants that the biggest impetus behind their research practice is because of external and introjected regulations. This refers to requirements such as graduation requirement from bachelor/ master courses and requirement as a university lecturer to conduct research; students' learning and teachers' own career development. As put by Hoang "My main motivation is to complete the required scores of research for the school. After the research, I receive the results on my students, that's also a motivation. But it was not a big one from the start. For the long term, of course, research has a lot of impact on my career too. It's highly beneficial to study for post doc degree, to apply for scholarships and have a better profile."

Said Phuong "The first thing is the requirement of the faculty, every year we need to conduct research for at least 600 hours. Secondly, the 2 research I have conducted this year it is because of the task I was assigned by the division in the faculty because I was member of the AUN group we need to conduct some survey, some research to write some report for AUN."

"Mostly I have to do research because I'm required to do it. For example, regarding the graduation from $B A$ degree, I was required to complete a graduation thesis to graduate the university with a Fast track program degree. Now, I'm required by university to conduct research in order to earn enough research grades for a year. Also, some of that would be the requirement of study for higher education." - Binh.

"I think if we conduct a research, Imean real research that you have motivation to do it and you really want to conduct, it gives us overview in teaching, also we can learn some interesting ways to plan lessons to organize activities in class, in a micro environment, maybe it is the way for us to material development, program development." - Phuong

Binh also mentioned some identified regulations as her motivation namely being a role model for her students, becoming more open minded and inquiring "I think lecturer has to be a good model for her students, so the lecturer has to do research. Also, by doing research, we're exposed to a lot of different ideologies, perspectives about an issue so we'd be more open minded. For example, I've read articles and comments about the age of letting our children learn English. Before, I didn't think much about it, but after reading those comments, that somehow, like, stimulates my inquiring mind."

On the other hand, the teachers did not forget to mention some intrinsic motivations in conducting research. Ha expressed her love for the activity itself, saying "When I teach, I have a lot of question, and I really want to do research to find answers. I love doing research, I love collecting data and coming up with different answers with my questions."

Similarly, intrinsic motivation also involves seeking and conquering challenges, 
which was showed in An's great passion for learning through research "For the graduation thesis, we had 2 choices, the $1^{\text {st }}$ one we could take some alternative courses to graduate - but then I wanted to challenge myself. I heard from some teachers saying that doing research might provide you the skill to search for information, to train yourself in the future. I want to challenge myself despite the fact that I knew it would cost me a lot of time and efforts... The strongest motivation for me is the quest for knowledge, the satisfaction of discovering something new.

In conclusion, the participants in the study claimed to conduct research mainly out of extrinsic motivation especially the least autonomous types of extrinsic motivation like external regulation and introjected regulation. Whereas, only two of them had intrinsic one such as their love for discovering new knowledge and challenging themselves by doing research.

\section{Discussion}

The findings of the study generally match with those of previous studies (Hancock, 2007; Ulla, 2018) in that the young teachers showed a general lack of confidence and even negative feelings associated with doing research despite acknowledging certain foundation in research methodology. As pointed out by numerous studies in psychology, one's psychological state could affect their performance. Steele and Aronson (1995), Aronson et al. (1999), Gutbezhalh (1995), Bouffard-Bouchard (1990), Lane et al. (2004) find that self-efficacy, stress, mood, anxiety can affect performance in different kinds of tasks ranging from cognitive to physical ones. Accordingly, positive selfefficacy and low level of stress seem to indicate better performance whereas negative selfefficacy, high stress and anxiety level are often associated with worse performance. As a result, the participants' lack of confidence in their ability to conduct research is likely to affect their research outcomes in one way or another, predictably towards the more negative end, especially when they have reported negative feelings in this practice themselves.

Moreover, in sharp contrast to results of Borg (2009), Mehrani (2015) and Ulla (2018), the participants in the current study had a mix of both intrinsic and extrinsic motivations, with the latter seemingly overshadowing the former. On a special note, the participants tended to largely perceive research as a required practice if they wish to gain certain qualification or continue their career rather than something they genuinely enjoy doing. In details, the external motivations that were reported by participants had to do with the less autonomous regulation types which in turn are likely to come with effects such as "less interest, value and effort toward achievement" (Ryan \& Deci, 2000b). This finding with the prevailing extrinsic motivation may be correlated to the low level of confidence and negative feelings associated with research activity reported earlier by the teachers as it has been found by previous research that extrinsic motivation is more closely linked with less confidence, greater anxiety as well as less positive emotions in the task involved (Deci \& Ryan, 1991; Wolters, Yu, \& Puntrich, 1996; Sénécal, Koestner, \& Vallerand, 1995).

\section{Conclusion}

To summarize, six novice teachers who participated in the research seemed to report a relatively low level of self-confidence in their research capability and somewhat more negative feelings towards this practice. As regards their motivations, they point to more extrinsic motivations such as requirements from school authority but do acknowledge that research doing is beneficial for their own career development and instructional activities in class.

\section{Limitations and suggestions for further research}

Due to the nature of qualitative research and interview instrument, the research outcomes 
tend to be highly subjective. The question log was designed by the researcher herself and has not been subjected to peer evaluation, so there may remain validation issues with it. The small number of participants also means that the outcomes cannot be generalized to present the opinion of the larger population of novice teachers, either in the faculty or on a wider scale. Also, it is acknowledged by the researcher herself that these interviews were conducted on single-time basis with no follow-up interview so the results could be somehow limitedly explored. Further study could be conducted into real difficulties for teachers in doing research as well as specific levels of adjustments that should be made to ensure novice teachers are better supported in research activities. Moreover, the researcher also hopes to conduct a follow-up research into specific difficulties facing the 6 participants in the current study related to their working environment. Another important question that needs to be answered is the level of confidence and motivation to do research among more experienced teachers in the faculty.

A more detailed look at the results also reveals that among the teachers who took part in this research, those with the least experience in teaching and research activities (Phuong and An) tended to be less confident in their research skills, but were more motivated by intrinsic factors (the discovery of new knowledge through researching) compared to the other teachers. This also poses an interesting finding that deserves further investigation in the follow up research.

\section{References}

\section{Vietnamese}

Phan Thị Tú Nga (2011). Thực trạng và các biện pháp nâng cao hiệu quả hoạt động nghiên cứu khoa học của giảng viên tại Đại học Huế. Tạp chí khoa học Đại học Huế, 68, 67-78.

\section{English}

Aronson, J., Lustina, M. J., Good, C., Keough, K., Steele, C. M., \& Brown, J. (1999). When white men can't do math: Necessary and sufficient factors in stereotype threat. Journal of Experimental Social Psychology, 35(1), 29-46.

Bandura, A. (1977). Self-efficacy: toward a unifying theory of behavioral change. Psychological Review, 84(2), 191.

Borg, S. (2009). English language teachers' conceptions of research. Applied Linguistics, 30(3), 358-388.

Bouffard-Bouchard, T. (1990). Influence of self-efficacy on performance in a cognitive task. The Journal of Social Psychology, 130(3), 353-363.

Chow, K. C. K., Chu, S. K. W., Tavares, N., \& Lee, C. W. Y. (2015). Teachers as Researchers: A Discovery of Their Emerging Role and Impact through a School-University Collaborative Research. Brock Education: A Journal of Educational Research and Practice, 24(2), 20-39.

Craig, C. (2007). Creating Confidence. A handbook for professionals working with young people. Glasgow: Centre for Confidence and Well- being.

Deci, E. L, \& Ryan, R. M. (1985). Intrinsic motivation and self-determination in human behavior. New York: Plenum.

Deci, E. L, \& Ryan, R. M. (1991). A motivational approach to self: Integration in Personality. In R. Dienstbier (Ed.), Nebraska Symposium on Motivation: Vol. 38. Perspectives on motivation (pp. 237-288). Lincoln: University of Nebraska Press.

Dickson, M., Riddlebarger, J., Stringer, P., Tennant, L., \& Kennetz, K. (2014). Challenges faced by Emirati novice teachers. Near and Middle Eastern Journal of Research in Education, 4.

Gray, J., \& Campbell-Evans, G. (2002). Beginning teachers as teacher-researchers. Australian Journal of Teacher Education, 27(1), 4.

Gutbezahl, J. (1995). How Negative Expectancies and Attitudes Undermine Females' Math Confidence and Performance: A Review of the Literature.

Hancock, R. (1997). Why are class teachers reluctant to become researchers?. British Journal of In-service Education, 23(1), 85-99.

Hargreaves, D. (2001). Revitalising educational research: past lessons and future prospects. Taking education really seriously: Four years. Hard Labour: RoutledgeFalmer.

Kincheloe, J. L. (2012). Teachers as researchers (classic edition): Qualitative inquiry as a path to empowerment. Routledge.

Kirkwood, M., \& Christie, D. (2006). The role of teacher research in continuing professional development. British Journal of Educational Studies, 54(4), 429-448. 
Lankshear, C., \& Knobel, M. (2004). A Handbook for Teacher Research: From Design to Implementation. Open University Press.

Lane, J., Lane, A. M., \& Kyprianou, A. (2004). Selfefficacy, self-esteem and their impact on academic performance. Social Behavior and Personality: an international journal, 32(3), 247-256.

Lyle, S. (2003). An investigation into the impact of a continuing professional development programme designed to support the development of teachers as researchers in South Wales. Journal of In-Service Education, 29(2), 295-314.

McNiff, J., \& Whitehead, J. (2012). Action research for teachers: A practical guide. David Fulton Publishers.

Mehrani, M. B. (2015). English Teachers' Research Engagement: Level of Engagement and Motivation. Iranian Journal of Language Teaching Research, 3(1), 83-97.

Richards, J. C., \& Lockhart, C. (1994). Reflective teaching in second language classrooms. Cambridge University Press.

Rowland, S. (1996). Relationships between teaching and research. Teaching in Higher Education, 1(1), 7-20.

Ryan, R. M., \& Deci, E. L. (2000a). Intrinsic and extrinsic motivations: Classic definitions and new directions. Contemporary Education Psychology, 25(1), 54-67.
Ryan, R. M., \& Deci, E. L. (2000b). Self-determination theory and the facilitation of intrinsic motivation, social development, and well-being. American Psychologist, 55(1), 68.

Sénécal. C., Koestner, R., \& Vellerand, R. J. (1995). Selfregulation and academc procrastination. Journal of Social Psychology, 135, 607-619.

Steele, C. M., \& Aronson, J. (1995). Stereotype threat and the intellectual test performance of African Americans. Journal of Personality and Social Psychology, 69(5), 797.

Ulla, M. B. (2018). Benefits and challenges of doing research: Experiences from Philippine public school teachers. Issues in Educational Research, 28(3), 797-810.

University of Languages and International Studies, 2017. Decision: Requirements of research and knowledge transferring for lecturers at University of Languages and International Studies, VNU. Hanoi: ULIS.

Watkins, A. (2006). So what exactly do teacherresearchers think about doing research? Support for Learning, 21(1), 12-18.

Wolters, C. A., Yu, S. L., \& Pintrich, P. R. (1996). The relation between goal orientation and students' motivational beliefs and self-regulated learning. Learning and Individual Differences, 8, 211-238.

Vietnam National University, 2014. VNU Development Strategies to 2020. Hanoi: VNU.

\title{
MỨC ĐỘ TỬ TIN VÀ ĐỘNG LỰC NGHIÊN CÚU KHOA HỌC CỦA GIÁO VIÊN TRẺ DẠY TIẾNG ANH TẠI ĐHQG HÀ NỘI
}

\author{
Lê Thùy Lân \\ Khoa Su phạm tiếng Anh, Trương Đại học Ngoại ngũ, ĐHQG Hà Nội \\ Phạm Văn Đồng, Cầu Giấy, Hà Nội, Việt Nam
}

Tóm tắt: Nghiên cứu này tìm hiểu mức độ tự tin và động lực của các giáo viên trẻ dạy tiếng Anh trong công tác nghiên cứu khoa học như là bước đầu để thực hiện các nghiên cứu sâu hơn về hoạt động nghiên cứu khoa học của giảng viên trẻ. Người nghiên cứu chọn hướng nghiên cứu định lượng thông qua phỏng vấn trực tiếp với sáu giáo viên tiếng Anh trẻ đang công tác tại Đại học Quốc gia Hà Nội. Kết quả nghiên cứu cho thấy các giáo viên có mức độ tự tin từ thấp đến trung bình về khả năng nghiên cứu của mình cũng như có động lực ngoại tại là chính, bao gồm yêu cầu nghiên cứu từ phía nhà trường và họ thừa nhận những lợi ích của nghiên cứu đối với việc dạy học cũng như phát triển chuyên môn của mình.

Tù̀ khoá: phát triển chuyên môn cho giáo viên, nghiên cứu khoa học, tự tin, động lực 